Published in Sociological Perspectives 58(3): 422-440.

https://doi.org/10.1177/0731121415577724

\title{
A More Perfect Union? Christian Nationalism and Support for Same-Sex Unions*
}

\author{
Andrew L. Whitehead \\ Department of Sociology and Anthropology \\ Clemson University \\ Samuel L. Perry \\ Department of Sociology \\ University of Oklahoma
}

How do overlapping social identities shape Americans' views toward contemporary social and moral issues? Drawing upon national-level data and employing the theoretical construct of social identity complexity, we examine the link between Christian nationalism-representing a convergence of national and religious identities-and Americans' views toward same-sex marriage and civil unions. Multivariate analyses reveal that greater adherence to Christian nationalism is strongly and negatively related to support for both same-sex marriage and civil unions, even after controlling for political ideology, religious controls, attribution of homosexuality, and other relevant correlates. We argue that Christian nationalists, who by definition internalize a high degree of overlap between political and religious identities, are more likely to see gays and lesbians as out-groups and same-sex unions as a threat to their sense of self and community. We conclude by discussing the implications of this study for future research on political and religious identities and intolerance toward socially marginalized populations.

\footnotetext{
* Please direct all correspondence to Andrew L. Whitehead, Department of Sociology and Anthropology, Clemson University, 132 Brackett Hall, Clemson, SC 29634, USA. Email: alw6@clemson.edu.
}

Author notes: An earlier version of this article was presented at the 2014 Society for the Scientific Study of Religion annual meeting. The authors would like to thank the editors of Sociological Perspectives and anonymous reviewers for their thoughtful and constructive advice. The authors would also like to acknowledge Kelly Whitehead and Jill Perry for their continued support. 
American's attitudes toward same-sex unions are undergoing dramatic change. The tide has clearly turned toward equality in marriage rights for gays and lesbians both in the minds of Americans and in the judicial and legislative bodies of government at the federal, state, and community levels. Despite these dramatic shifts, it is unmistakable that a significant minority of Americans still oppose same-sex unions. According to the 2012 General Social Survey, four out of 10 Americans disagree or strongly disagree with gay marriage. ${ }^{1}$ Continued resistance is also observed within the political sphere. Some states, like Indiana in early 2014, are debating constitutional amendments that completely outlaw same-sex marriage (Indiana Marriage Protection Amendment HJR3). At the federal level, Rep. Randy Weber (R-TX) proposed a "State Marriage Defense Act” (H.R. 3829) in January of 2014 that would keep the federal government from recognizing the marriages of same-sex couples who live in states where samesex marriage is not legal (Benen 2014).

In seeking to better understand what social factors contribute to this continued resistance to same-sex unions, we examine the extent to which overlapping social identities may serve to promote intolerance toward perceived out-groups and their claims to equality. To do so we draw on the theoretical construct of social identity complexity and utilize Christian nationalism, the belief that (1) God chose the U.S. and (2) the U.S. must follow God's commands to flourish, as an empirical case of conflated national and religious identities. We find that individuals with single convergent social identities, like Christian nationalism, are much more likely to exhibit intolerance toward the civil rights of perceived out-groups, like gays and lesbians. This research makes three important contributions. First, prior research on social identity complexity focuses primarily on attitudes toward immigrants or racial out-groups and does not examine attitudes toward moral issues. This study is the first to provide support for the utility of social identity 
complexity when examining such attitudes. It also demonstrates the utility of the concept of social identity complexity using a large, national random sample dataset. Second, prior research on attitudes toward same-sex unions highlights the importance of religion and politics in shaping individual attitudes. However, no prior research investigates how the intertwined nature of religion and politics in the minds of Americans is associated with attitudes toward same-sex unions. Using the concept of Christian nationalism, this study highlights how a particular religiopolitical social identity influences attitudes above and beyond the standard religion and politics measures. Third, this research clearly shows that Christian nationalism is strongly associated with intolerance toward same-sex unions, despite some claims that beliefs about the Christian heritage of the United States is merely an attempt at creating and maintaining a collective identity (Smith 2000). Our findings interpreted through the lens of social identity complexity theory demonstrate that when particular collective identities become single convergent social identities, intolerance toward perceived out-groups will likely result.

\section{Religion, Politics, and Attitudes toward Same-Sex Unions}

Religion, measured as affiliation, behavior, or belief, is consistently associated with attitudes toward same-sex unions. Evangelical and Black Protestants are generally opposed to same-sex unions while Catholics, Mainline Protestants, Jews, and the religiously unaffiliated tend to be more supportive (Andersen \& Fetner 2008; Olson, Cadge, and Harrison 2006; Whitehead 2012). Turning to religious behaviors, extant research shows that individuals who attend religious services more, pray more, or read sacred scriptures more tend to be more opposed to same-sex unions than those who practice these behaviors less frequently (Andersen \& Fetner 2008; Burdette, Ellison, and Hill 2005; Perry 2013; Olson et al. 2006; Whitehead 2010). Religious belief is also predictive of attitudes toward same-sex unions. Individuals who hold 
more traditional religious beliefs, like the Bible should be read literally, are more opposed to same-sex unions (Burdette et al. 2005; Hill, Moulton, and Burdette 2004; Perry 2013; Sherkat et al. 2010; Sherkat et al. 2011; Whitehead, 2010). Also, those who hold traditional beliefs about God, such as whether God is best understood in masculine terms, as actively involved in the world, or judgmental of it, also tend to oppose same-sex unions (Froese and Bader 2010; Whitehead 2010, 2014a).

Individuals who identify as politically conservative are the most opposed to same-sex unions while individuals who identify as politically liberal are most supportive (Haider-Markel and Joslyn 2008; Hill et al. 2004; Sherkat et al. 2011). Similarly, self-identified Republicans are most opposed to same-sex unions, while independents are more supportive, with self-identified Democrats being the most supportive (Sherkat et al. 2011). In fact, political conservatism partially mediates the negative attitudes Evangelicals hold toward homosexuality (Hill et al. 2004). These findings hint at the interwoven nature of religion and politics regarding attitudes toward same-sex unions. However, as Sherkat and colleagues (2011) point out, the opposition of political conservatives is not simply due to the large number of conservative Christians in their ranks, and the antagonism of conservative Christians toward same-sex unions is not merely due to their conservative political views.

Clearly, religion and political views robustly and consistently predict support or opposition of same-sex unions. It is also clear that these two social institutions are closely linked in the American social context. Since the rise of the religious right, through the Bush presidency, and on through the various grassroots movements that sprung up during the Obama years in the White House (like the Tea Party), political and religious themes are used simultaneously to provide support for stances on key social issues (Froese and Mencken 2009; Skocpol and 
Williamson 2012). Prior research demonstrates that individuals' religious and political views are intertwined on the same-sex unions issue using various measures and statistical analysis techniques. What remains to be seen is how tightly bundled religio-political identities can influence attitudes toward same-sex unions above and beyond the previously utilized measures of political conservatism and religious affiliation, belief, and behavior. It is this issue upon which our study focuses.

\section{Social Identity Complexity and Christian Nationalism}

The theoretical construct of social identity complexity (SIC) refers to individuals' subjective representation of the overlapping nature of their multiple in-group identities (Roccas and Brewer 2002). SIC represents the interrelationships people perceive between the groups with which they identify. While all individuals are clearly members of many different groups, the actual complexity of a person's cross-cutting group membership is irrelevant. Rather, SIC hinges on individuals' subjective representation of their multiple identities. Roccas and Brewer (2002) argue that SIC operates on a continuum that ranges from relatively simple social identity complexity to more complex social identities. High complexity individuals perceive relatively little overlap in their multiple membership groups, employ a more inclusive definition of ingroup, and make no sharp distinctions regarding in-groups and out-group. Low social identity complexity occurs when individuals' multiple identities are subjectively rooted in a single ingroup representation resulting in a single highly exclusive social category. For those with low

social identity complexity, only people who share membership on the most salient social categories are in-group members. Again, the actual complexity of an individual's social memberships is irrelevant. What matters is whether or not the individual perceives her multiple 
identities as largely overlapping. When multiple group memberships are perceived as generally coinciding, the different in-groups are conceived as a single convergent social identity.

Belief that the United States is a Christian nation is an instance where individuals perceive two different in-groups, one religious (Christians) and one political (United States citizens), as consisting of largely overlapping memberships. A person who views the United States as a Christian nation will likely believe (explicitly or implicitly) that to be a "true" American one must be Christian. In the same way, even if they objectively know that not all Christians are Americans, they could still believe that "their" kind of Christians are American. Those who believe the United States is a Christian nation are displaying a relatively simplified social identity structure. And, as SIC predicts, when individuals perceive their religious and political group memberships as generally coinciding, a single convergent social identity is the result: Christian nationalism.

The belief that the United States is a Christian nation hinges on a particular interpretation of U.S. history as God-ordained. As Wuthnow (1988) points out, since WWII there are both liberal and conservative versions of American civil religion. The liberal version views America and its purpose as one where its resources must be used to alleviate the world's problems. The conservative version focuses on the nation's founding, and it's supposed divine origin. In this particular retelling, the Puritans and the founding fathers of the United States established a covenant with the Christian God (Bellah 1976; Burdette et al. 2005; Wuthnow 1988). This narrative contains the two major tenets of Christian nationalism: (1) the United States is God's chosen country, a "city on a hill", and (2) to maintain that chosen status, to flourish, the United States must uphold God's commands and not break the covenant. Again, as Wuthnow (1988) points out, biblical ideals are central to the conservative version of American civil religion. 
These tenets were most clearly articulated by the various leaders of the religious right in the 1970s and 1980s. As Jerry Falwell, a leader of the Moral Majority, points out: "The wicked shall be returned to hell, and all the nations that forget God. America will be no exception. If she forgets God, she too will face his wrath and judgment like every other nation in the history of humanity" (Falwell 1980:24, as cited in Burdette et al. 2005). In their view, the U.S. was founded as a Christian nation, it had since lost its way, but through political means the U.S. could once again hold up its end of the covenant by returning to its biblical ideals and bring God's blessing back on the country (Wuthnow 1988; see Sutton 2012). The religious right believed that the United States was turning its back on God due to its changing stance on a number of issues like prayer in schools, abortion, and relaxed divorce laws. One cornerstone issue of the movement that continues to be salient is homosexuality.

Religio-political leaders and their followers believed that by extending legal protections to gays and lesbians, the United States was breaking its covenant with the Christian God, who in their view despises homosexuality. Essentially, these individuals believed that morality was more than a private affair, but a public one and subsequently fought for acceptance of their views toward homosexuality in the public sphere (Burdette et al. 2005; Regnerus and Smith 1998). In order for the U.S. to prosper, they believed the U.S. must follow their interpretation of the Christian God's view of homosexuality which they support in two related but distinct ways. The first is their interpretation of a number of specific Christian scriptures mentioning homosexuality (e.g. Leviticus 18:22; Leviticus 20:13; Romans 1:26-27; 1 Corinthians 6:9-11). These texts are interpreted literally and not contextually dependent, or in need of interpretation considering the era in which they were written. In their view, because the Bible is against homosexuality, the 
United States must not extend legal protections to gays and lesbians, especially the right to marry (Burdette et al. 2005; Fetner 2008).

A second reason why Christian nationalists believe God is opposed to homosexuality and same-sex unions in the United States is their unwavering belief in the traditional husband/wife marriage union as the only God-ordained union. ${ }^{2}$ Central to this worldview is the belief that men are supposed to be the heads of the marriage relationship and women are supposed to submit to that authority (Bartkowski 2001; Denton 2004). Traditional views of gender influence the ways in which Christian nationalists view same-sex unions because these views keep them from comprehending how authority and gender roles are understood in same-sex relationships. For gender traditionalists, authority and gender roles are paramount in the marriage relationship. In this way, same-sex marriage is to be opposed not only because the Bible forbids homosexuality, but also because same-sex marriages cannot represent the biblical ideal for marriage. Furthermore, the importance of traditional marriage for Christian nationalists is salient because the traditional family is believed to be the foundation of a stable society (Burdette et al. 2005). Same-sex marriage threatens the traditional view of marriage and as such is a threat to the most important component of a functioning, stable, society. ${ }^{3}$

\section{The Threat of Same-sex Unions}

Current scholarship points to perceived threats as an important antecedent to activating lower levels of social identity complexity. Perceived threats to a person's in-group, like Christian nationalism, raises the salience of the threatened in-group in relation to other groups due to the belief that the out-group is in some way detrimental to the in-group. This can also lead to stress for in-group members, which leads to further simplified representations of the in-group. When threatened, in-group members perceive their in-group as more homogenous, their selves as more 
similar to the in-group and more different from the out-group, and prefer clear in-group boundaries (Roccas and Brewer 2002). Levels of trust of the perceived out-group also decrease (Kuwabara et al. 2007). Essentially, perceived economic, political, or symbolic threats (such as values, trust, or morality) lead to lower social identity complexity (Brewer and Pierce 2005). Single convergent social identities are especially prone to perceived threats given that in-group members rely on group membership much more heavily than those with more complex social identities. For Christian nationalists, the threat of legal same-sex unions is overwhelming. Because they believe (1) God chose the U.S., (2) the U.S. must follow God's commands to flourish, and that (3) God forbids homosexuality and same-sex unions, any attempt to legalize same-sex unions is perceived as an attack on their Christian nation and, as SIC points out, their social identity. Such perceived threats lead to decreased social identity complexity for Christian nationalists leading to a wider gulf between their perceived in-group and everyone else. The social contamination literature also highlights this connection between threats and tolerance (Burdette et al. 2005). Christian nationalists view homosexuality, and same-sex unions, as threats or contaminants to American society and so they must be opposed.

When threats and resulting low social identity complexity lead to single convergent social identities like Christian nationalism, clear in-group boundaries begin to emerge. This leads to several theoretical reasons why Christian nationalism, an indication of low social identity complexity, leads to increased biases and discrimination toward the civil rights of out-groups like gays and lesbians. First, the lack of cross-cutting dissimilarities between the multiple identities makes social categorization less complex which leads to more distinct in-group/out-group differences. Christian nationalists perceive their in-group and the out-group or groups as increasingly homogenous, highlighting their differences. Second, the perception that multiple 
identities overlap increases the evaluative importance of the self for intergroup comparisons, encouraging motivation for intergroup discrimination. Third, less complex identities obscure the fact that in-group members on one or two dimensions could be out-group members on another. Christian nationalists overlook the complexity of their own in-group which makes it easier to demonize those who they perceive as holding nothing in common. Finally, a single convergent social identity reduces the awareness of other group memberships thus increasing the importance of the one social identity for satisfying needs for belonging and self-esteem (Brewer and Pierce 2005; Roccas and Brewer 2002). Christian nationalists see their single convergent identity as supremely important. The cross and the flag are intimately intertwined. Therefore, any perceived attack on this identity threatens their entire self-concept.

Christian nationalists who seek a Christian United States where the "boundaries of the religious and political communities [are] coterminous as possible" (Gorski 2010), oppose the legal recognition for same-sex marriage because it violates biblical injunctions against homosexuality and undermines the traditional family which God ordained as the foundation for a stable society (Burdette et al. 2005; Wuthnow 1988). Christian nationalists see same-sex marriages and civil unions as not only threats and social contaminants which must be opposed to ensure the continued goodwill of God toward the United States but also as threats toward their social identity (Roccas and Brewer 2002). Therefore, using the theoretical construct of social identity complexity we predict the following relationship between Christian nationalism and attitudes toward same-sex unions:

Net of all other effects, Christian nationalists will be less supportive of same-sex unions compared to individuals with lower levels of Christian nationalism.

\section{Data}


This study uses the 2007 Baylor Religion Survey (BRS) to investigate the relationship between Christian nationalism and attitudes toward same-sex unions. The 2007 BRS is a random, national survey of 1,648 English-speaking adults in the United States collected by the Gallup Organization. The survey utilized a mixed-mode sampling design consisting of twophases. The first phase screened 3,500 individuals where 2,460 possible respondents agreed to receive the questionnaire. A total of 1,648 questionnaires were returned, resulting in response rates of $47 \%[1,648 / 3,500]$ among all individuals screened and $67 \%[1,648 / 2,460]$ for those who agreed to receive a mailed survey. This response rate is within the normal parameters for RDD samples (see Froese and Bader 2010). See Bader, Mencken, and Froese (2007) for further information on the Baylor Religion Survey's overall methodology.

One weakness of using data from 2007 to investigate attitudes toward same-sex unions is that attitudes have shifted. For this reason, the findings of this study should be interpreted with caution. It may be that the relationship between Christian nationalism and support of same-sex unions is different now than in 2007. However, it could also be that these relationships are for the most part unchanged, even if overall support of same-sex unions has increased. We return to this issue in greater detail in the discussion section.

\section{Dependent Variable}

We utilize two questions to assess attitudes toward same-sex unions. The first asks for respondents' level of agreement (Strongly agree to Strongly disagree) with the following statement: "Homosexuals should be allowed civil unions." The second asks for respondents' level of agreement (Strongly agree to Strongly disagree) with: "Homosexuals should be allowed

to marry." ${ }^{4}$ Responses for both questions were dichotomized where 1 = "Strongly agree" and 
“Agree." Overall, 55.8 percent of the sample support same-sex civil unions, and 33.4 percent support same-sex marriage.

\section{Independent Variable}

Six questions pertaining to Christian nationalism were used to create a summed index. The questions used to create the index were the following: "To what extent do you agree or disagree that the federal government should declare the United States a Christian nation?", "To what extent do you agree or disagree that the federal government should advocate Christian values?", “To what extent do you agree or disagree that the federal government should enforce strict separation of church and state?" (the responses to this question were recoded in order to match the direction of the other five questions), "To what extent do you agree or disagree that the federal government should allow the display of religious symbols in public spaces?", "To what extent do you agree or disagree that the federal government should allow prayer in public schools?", and "Please indicate your level of agreement with the following statements about world events: the success of the United States is part of God's plan." Possible response categories ranged from "Strongly agree" to "Strongly disagree." All questions loaded onto one factor with scores above 0.76 . The overall alpha coefficient for the index is 0.87 . The index ranges from $6=$ Low Christian Nationalism to $30=$ High Christian Nationalism. The mean score is 17.98 with a standard deviation of 6.41 (see Table 1$)^{5}$

Prior research operationalized social identity complexity by asking respondents to identify various groups with which they identify (Brewer et al. 2013; Brewer and Pierce 2005; Roccas and Brewer 2002). McDaniel and colleagues (2011) operationalized social identity complexity and Christian nationalism through creating an index of six questions similar to those used in the 2007 BRS. The index constructed for this analysis follows McDaniel et al.'s (2011) 
work by utilizing six questions pertaining to Christian nationalism, as described in the previous

paragraph. While useful, there are two weaknesses with this strategy that deserve mention. First, it should be noted that this measure does not assess the totality of each individual's social identity. However, to do so is not our goal. Instead, we are interested in discovering if varying levels of complexity of an aspect of one's total social identity can meaningfully influence their views on an important social issue like gay marriage. Second, a low score on the index does not necessarily imply a complex social identity with regards to religion and nationalism. For example, a respondent could believe that secular Americans are the only "true Americans", thus exhibiting a simple social identity structure. While plausible, research shows secular Americans tend to be much more accepting of alternative worldviews (Karpov 2002) making it very unlikely that they would envision their religio-political identity as the only proper way to "be American."

\section{Control Variables}

A variety of religion and socio-demographic control variables are used to ensure the association between Christian nationalism and attitudes toward same-sex unions is non-spurious and robust. We control for the effects of religious tradition using Steensland et al.'s (2000) typology that identifies individuals as Evangelical Protestants, Mainline Protestants, Black Protestants $^{6}$, Catholics, Jewish, Other, and no affiliation. ${ }^{7}$ To account for religious practice we construct a scale using the standardized and summed responses to frequency of worship service attendance, frequency of sacred scripture reading, and frequency of prayer. Each religious practice loads onto the same factor with scores above 0.84 . The alpha coefficient for the scale is 0.84. The analysis also includes a series of dichotomous variables that measures respondents' views of the Bible. The 2007 BRS asked, "Which one statement comes closest to your personal 
beliefs about the Bible?" Possible responses were "The Bible means exactly what it says. It should be taken literally, word-for-word, on all subjects;" "The Bible is perfectly true, but it should not be taken literally, word-for-word. We must interpret its meaning;" "The Bible contains some human error;" "The Bible is an ancient book of history and legends;" and "I don't know." Because biblical literalists tend to be most opposed to same-sex unions, we exclude them as the contrast category in the full model. We also control for the belief that God is a "he" $(1=$ God is a "he").

In addition to religion, the other key control variables are ideological in nature. One of the most important in the model is political ideology. The 2007 BRS asks, "How would you describe yourself politically?" Possible responses range from "Extremely conservative" to "Extremely liberal." ${ }^{8}$ The next ideological control concerns beliefs about the cause of homosexuality, which prior research indicates is predictive of same-sex union attitudes (Whitehead 2010). This analysis controls for the belief that homosexuality is innate ( $1=$ homosexuality is innate). The final ideological control concerns gender-role attitudes. Prior research shows that traditional gender role beliefs strongly predict attitudes toward homosexuality and same-sex unions. We therefore include a traditional gender-role beliefs index. The index consists of four items that ask for respondents' level of agreement $(1=$ Strongly Disagree to 5 = Strongly Agree) to the following statements: "Most men are better suited emotionally for politics than most women," "A preschool child is likely to suffer if his or her mother works," "It is God's will that women care for children," and "A husband should earn a larger salary than his wife." These items are widely used when constructing gender ideology indexes (see Davis and Greenstein 2009) and predictive of attitudes toward same-sex unions. The alpha reliability coefficient for the index is 0.74 . The gender-role traditionalism index ranges 
from 4 to 20 . The mean value for the index is 9.95 with a standard deviation of 3.69 (see Table 1). Higher scores on the index equate to more traditional gender-role beliefs.

The socio-demographic controls in this analysis are age (in years), gender $(1=$ female), race $(1=$ non-white $)$, region $(1=$ South $)$, marital status $(1=$ married $)$, income $(1=\$ 10,000$ or less to $7=\$ 150,000$ or more $)$, and education $\left(1=8^{\text {th }}\right.$ grade or less to $7=$ postgraduate work/degree).

\section{Plan of Analysis}

We first present descriptive statistics for all of the dependent, independent, and control variables in table 1 . We then display, also in table 1, the bivariate associations between the independent variables and the dependent measures. Figure 1 highlights the bivariate relationship between Christian nationalism and support for same-sex unions. We then move on to multivariate analyses in tables 2 and 3 and we present the results of four binary logistic regression models for each dependent variable. We use binary logistic regression due to the dichotomous coding of the dependent variables (Pampel 2000). In addition to odds ratios, we also report standardized coefficients to allow for the interpretation of substantive significance alongside statistical significance. ${ }^{9}$ We present 4 models total adding in variables step-wise in order to examine changes as subsequent controls are added in. Model 1 displays all of the religion, socio-demographic, and ideological controls without the Christian nationalism measure. Model 2 contains the Christian nationalism measure with each of the religion controls. Model 3 adds the socio-demographic controls. Model 4 displays the full model with the ideological controls included. ${ }^{10}$ Finally, in figure 2 we present the predicted probabilities of support for same-sex marriage and civil unions at varying levels of the Christian nationalism scale. ${ }^{11}$ To account for missing data we utilize multiple imputation (MI) techniques (Rubin 1996). ${ }^{12}$ 


\section{Results}

In table 1 we find that Christian nationalism is strongly correlated with each dependent variable. Figure 1 displays this bivariate association. At the lowest points of the Christian nationalism scale, $95 \%$ and $87 \%$ of respondents support civil unions and same-sex marriage, respectively. At the highest levels of Christian nationalism, only $11 \%$ and $5.6 \%$ of respondents support civil unions and same-sex marriage.

\section{TABLE 1 ABOUT HERE}

\section{FIGURE 1 ABOUT HERE}

Table 2 contains the results for support of same-sex marriage. Model 1 includes all of the controls without the Christian nationalism scale. Black Protestants are less supportive of samesex marriage than Evangelicals. Those who believe the Bible contains errors, or that it is a book of history and legends are more supportive of same-sex marriage than biblical literalists. Individuals who regularly practice their religion are also less supportive, along with older individuals. Ideologically, those who are politically conservative and who hold traditional gender-role ideologies are much less supportive of same-sex marriage, while those who believe homosexuality is innate are much more supportive. Across models 2 and 3 we see that the Christian nationalism scale is significant as controls are added, and maintains that significant association $(\mathrm{p}<.01)$ in the final model. As Christian nationalism increases, support for same-sex marriage decreases. In fact, for each point increase on the Christian nationalism scale, the odds of supporting same-sex marriage decrease by six percent. ${ }^{13}$ Substantively, the Christian nationalism scale is the fifth strongest predictor in the model $(\beta=-0.20)$. Political conservatism is the strongest predictor $(\beta=-.48)$ and those who rate themselves as politically conservative are much less supportive of same-sex marriage. Those who believe homosexuality is innate are 
supportive of same-sex marriage $(\beta=0.33)$, while gender traditionalists are not $(\beta=-0.20)$. Individuals who believe the Bible contains errors $(\beta=0.16)$ or that it is a book of legends $(\beta=$ 0.29) are more supportive of same-sex marriage compared to biblical literalists. Older individuals $(\beta=-0.11)$ and those who practice their religion regularly $(\beta=-0.18)$ are both less supportive of same-sex marriage. The changes across models in the proportional reduction in error (PRE) highlight an improved prediction of support for same-sex marriage.

\section{TABLE 2 ABOUT HERE}

Table 3 turns to attitudes toward same-sex civil unions. Model 1 again contains all of the control variables without the Christian nationalism scale. Those who believe the Bible should be interpreted, that it contains errors, or that it is an ancient book are all more supportive of civil unions compared to biblical literalists. Those who practice their religion regularly or believe that God is a "he" are more opposed to civil unions. Increasing levels of education and income predict more support for civil unions, while being from the south predicts opposition. Political conservatives, and those with traditional gender ideologies, are both less supportive of civil unions. Believing homosexuality is innate predicts support of civil unions. In models 2 and 3 increasing Christian nationalism is strongly and negatively associated with support for civil unions as control variables are added. In the full model displayed in model 4, Christian nationalism is the second strongest predictor in the model $(\beta=-0.30)$ and for every point increase in Christian nationalism, the odds of support for civil unions decrease almost nine

percent. ${ }^{14}$ Believing homosexuality is innate indicates support and is the strongest predictor $(\beta=$ 0.37). Biblical interpreters $(\beta=0.23)$, those who believe the Bible contains errors $(\beta=0.23)$, and those who believe it is only an ancient book $(\beta=0.29)$ are all more supportive of civil unions than biblical literalists. Women $(\beta=0.08)$ and those with higher levels of education $(\beta=0.19)$ or 
income $(\beta=0.15)$ are all more supportive of civil unions. Those who practice their religion regularly $(\beta=-0.17)$ and those from the south $(\beta=-0.10)$ are each less supportive. Surprisingly, political ideology is not significantly associated with attitudes toward civil unions once Christian nationalism is accounted for in the model. While political conservatism was strongly and negatively associated with support for civil unions $(\beta=-0.13)$ in model 1 , it is non-significant in model 4. As with same-sex marriage, the changes in the PRE across all models highlights the improved prediction of attitudes toward same-sex civil unions.

\section{TABLE 3 ABOUT HERE}

Figure 2 displays support for our hypothesis by graphing the predicted probabilities of support for same-sex marriage and civil unions at varying levels of Christian nationalism. All significant effects in each final model are held at their means. At the lowest levels of Christian nationalism, over eight in ten respondents support civil unions while three in ten support samesex marriage. At the midpoint of the Christian nationalism scale, almost seven in ten are supportive of civil unions, while almost two in ten are supportive of same-sex marriage. At the highest levels of Christian nationalism only four in ten respondents support civil unions, while just one in ten are supportive of same-sex marriage. From the lowest levels of Christian nationalism to the highest levels of Christian nationalism, the predicted probability of supporting same-sex civil unions decreases by 50 percent $(0.43 / 0.85)$ whereas the predicted probability of supporting same-sex marriage decreases by almost a third (0.10/0.31).

FIGURE 2 ABOUT HERE

\section{Discussion}

Christian nationalism, the degree to which Americans envision the United States as Christian in its identity, values, sacred symbols, and policies, is clearly associated with attitudes 
toward official recognition of same-sex relationships. Those who do not perceive a large degree of overlap between their "American" and "Christian" identities are much less likely to discriminate toward others, in this case gays and lesbians. Christian nationalists who perceive a large degree of overlap between their religious and political identities are much more likely to perceive gays and lesbians as an out-group and deserving of discrimination by way of limiting access to same-sex marriage and civil unions. Christian nationalists oppose same-sex unions because of their commitment to a particular national narrative that (1) the United States is God's chosen country, (2) to flourish the United States must uphold God's commands, and (3) samesex unions are in conflict with God's commands. For Christian nationalists moral issues are inherently public issues and the threat of social contamination they perceive in same-sex unions leads them to oppose both same-sex marriage and same-sex civil unions so that America might conform to a biblical ideal (Burdette et al. 2005; Regnerus and Smith 1998; Wuthnow 1988).

Prior research on religion, politics, and attitudes toward same-sex unions demonstrates that religious affiliation, religious beliefs, religious practices, and political ideology are all important predictors (Andersen \& Fetner 2008; Burdette et al. 2005; Hill et al. 2004; Perry 2013; Olson et al. 2006; Sherkat et al. 2010; Sherkat et al. 2011; Whitehead 2010, 2012, 2014a, 2014b). However, prior research overlooked how tightly bundled religio-political identities can influence attitudes above and beyond these previously utilized measures. The present analyses extend this prior work on same-sex union attitudes by showing that Christian nationalism - a tightly bundled religio-political identity - is significantly associated with views toward a moral issue being debated in the public sphere. Future research can continue to analyze how Christian nationalism is related to a variety of other attitudes and outcomes in the United States as well as how tightly 
bundled religio-political identities in other cultural contexts - for instance, largely Muslim nations - operate.

While the direction of the relationships between Christian nationalism and attitudes toward same-sex marriage and civil unions are identical, comparing the strength of these associations across models provides additional support for the unique importance of this measure. As previously mentioned, the Christian nationalism measure is the fifth-strongest measure in the marriage model while being the second-strongest when predicting attitudes toward civil unions. The standardized coefficient for Christian nationalism in the civil unions full model is also 50 percent larger than the standardized coefficient in the marriage full model. Finally, figure 2 shows that the predicted probability of supporting civil unions decreases by 50 percent while the probability of supporting same-sex marriage decreases by only a third. Taken together, these results suggest that increasing levels of Christian nationalism is more strongly associated with opposition toward civil unions than marriage. In effect, they see same-sex civil unions as just as much of an affront to their ideal America as same-sex marriage. The fact that the conservative political ideology measure is non-significant in the civil unions model again highlights the unique nature of the Christian nationalism measure. Political conservatives are opposed to same-sex marriage (see model 4, Table 2) but net of the effect of Christian nationalism in the civil unions full model (comparing models 1 and 4, Table 3), political conservatives are no different from political liberals. Here again we see that Christian nationalists are not just another brand of political conservatives. Their particular view of America and its religio-political heritage exhibit a unique and important association with samesex marriage and civil unions. While political conservatives might oppose same-sex marriage but relent somewhat concerning civil unions, Christian nationalists view both as social contaminants 
and equally threatening and destructive to their ideal America and its quest to adhere to a biblical ideal (Wuthnow 1988).

Taken together, these results also make clear that Christian nationalists are not merely religiously active, or religiously conservative, or a combination of these. If they were, the religion and ideological controls in the multivariate models would render the Christian nationalism measure non-significant. While this narrative is related to political conservatism, religious activity, and religious conservatism, it is not fully explained by those measures alone. Again, the particular narrative endorsed by Christian nationalists operates above and beyond the effects of political and religious conservatism. ${ }^{15}$

There are a number of other differences between the same-sex marriage and same-sex civil union models that deserve mention. First, we find that biblical literalists are no different from those who believe the Bible must be interpreted when considering same-sex marriage. Both groups are opposed to it. However, when considering same-sex civil unions, those who believe the Bible is true but must be interpreted are much more likely to support civil unions compared to biblical literalists. Here we see that those who believe the Bible is true but in need of interpretation make a distinction between same-sex marriage (which they oppose) and same-sex civil unions (which they are more likely to support). They appear to occupy a "middle-ground" on this issue. This finding is in line with other research (see Whitehead and Perry 2014) and provides further support for continuing to account for the multifaceted nature of views toward the Bible in future research. Finally, regarding the socio-demographic measures across models, we find that age is negatively and significantly related to same-sex marriage but has no association with civil unions. Gender, education, and income are all positively associated with same-sex civil unions but are unrelated to same-sex marriage. Conversely, being from the south 
is negatively associated with same-sex civil unions but unrelated to same-sex marriage. These results point to the fact that attitudes toward homosexuality and the civil rights of gays and lesbians are contingent on many factors and are not uniform. For many Americans attitudes toward gay civil rights depend on which civil right is in question.

Finally, these results provide further support for the usefulness of the theoretical construct of SIC by demonstrating its utility in predicting attitudes toward ideological and moral issues. Prior research using SIC focused on attitudes toward immigrant or other racial groups. By showing SIC can predict attitudes toward moral issues a number of avenues for future research are apparent. First, researchers should continue to examine what different types of moral attitudes are significantly associated with varying levels of social identity complexity. Such work will highlight how individuals' various identities and the interrelationships of those identities influence how they respond to issues prevalent in the public discourse. Second, researchers should consider what other types of social identities overlap in the minds of some individuals. Perhaps social identity complexity can extend into examinations of how religious and gender identities overlap, or political and class identities. It is important for social scientists to continue to examine the areas of overlap in individuals' identities because it gives some indication of how the influence of different social institutions operates at the individual level. As this analysis demonstrated, social institutions like religion and politics are internalized and mobilized in disparate ways. These differences then lead to vastly different outcomes in how individuals react to the world around them. Such reactions may serve to constrain interpersonal contact, which may further hinder any reduction in prejudice (Merino 2013; Schmid et al. 2012).

While we find strong support for the utility of social identity complexity and Christian nationalism when investigating attitudes toward same-sex unions, there are limitations that 
deserve mention. First, as mentioned earlier, the data for this study were drawn in 2007. American attitudes toward same-sex unions have shifted since then and will most likely continue to do so. Future research building off of this study using more recent data is needed. While this relationship may have changed since 2007, there is a strong possibility that it did not. Popular discourse, especially in religious circles, still utilizes a Christian nationalist bent when defending their opposition toward same-sex marriage (e.g. Sprigg 2011). It is also possible that the relationships explored in this study have increased in strength given that much of the shift in attitudes concerning same-sex unions occurred among less religious and politically moderate Americans while religious and political conservatives' views have become more polarized (Baunach 2011). One additional advantage of using the 2007 BRS is that it provides an important snapshot of how Americans' attitudes were structured at a time of great change in those attitudes. This can serve as a comparison for future analyses. Given that attitudes toward same-sex unions have changed so dramatically, something highly unusual, data from 2007 may be more important than we might otherwise expect. ${ }^{16}$ Furthermore, at this time, no other national data set contains questions on same-sex unions and Christian nationalist ideology which would permit an empirical test like the current study. Second, due to the cross-sectional nature of the data we are unable to establish causality. It may be that attitudes toward same-sex unions drive individuals to envision a closer relationship between their religious and political communities. Finally, the same-sex union measures conflate attitudes toward gay men and lesbians by asking for responses concerning "homosexuals." Prior research demonstrates that attitudes toward gay men and lesbians can vary. However (see endnote 4), the public rhetoric usually references "homosexuality" without distinguishing between lesbians and gay men. Therefore, these measures do tap into the broader set of attitudes maintained by the wider public. 


\section{Conclusion}

Using a national, random sample of American adults, this analysis demonstrates that Christian nationalists are much more likely to oppose same-sex unions than individuals who perceive less overlap between their religious and political identities. This finding makes three primary contributions. First, it highlights the utility of the theoretical construct of social identity complexity using a large, national random sample dataset and when examining attitudes toward moral issues. Second, this research demonstrates the importance of accounting for the interconnected nature of social institutions at the individual level. As Martin (2004:1258) points out, social institutions are in many ways intertwined with one another and "assuming any institution is separate from others produces flawed understanding." Prior research emphasized the influence of both religion and politics on individual attitudes, but overlooked their interconnected nature in the identities of individuals.

Finally, as Merino (2010) points out, despite claims that Christian nationalism is merely an attempt at creating and maintaining collective identity and is not overtly related to intolerance (Smith 2000), these findings suggest that single convergent social identities like Christian nationalism strongly promote intolerance toward same-sex unions. As individuals begin to represent their multiple identities as largely overlapping and perceive threats from out-groups to the values encouraged by their single convergent social identity, they will begin to discriminate between those who share the hallmarks of each identity and those who differ on even just one. In the case of same-sex unions, Christian nationalists place gays and lesbians firmly in an out-group and then oppose any attempt at allowing them access to a civil social institution that is infused with religious significance. 


\section{References}

Allison, Paul. 2001. Logistic Regression Using the SAS System: Theory and Application. New York. Andersen, Robert and Tina Fetner. 2008. "Cohort Differences in Tolerance of Homosexuality: Attitudinal Change in Canada and the United States, 1981-2000.” Public Opinion Quarterly 72:311-30

Bader, Christopher D., F. Carson Mencken, and Paul Froese. 2007. “American Piety 2005: Content, Methods and Selected Results from the Baylor Religion Survey." Journal for the Scientific Study of Religion 46:447-463.

Bartkowski, John P. 2001. Remaking the Godly Marriage: Gender Negotiation in Evangelical Families. New Brunswick: Rutgers University Press.

Baunach, Dawn M. 2011. "Decomposing Trends in Attitudes toward Gay Marriage, 1988-2006." Social Science Quarterly 92(2):357-374.

Bellah, Robert. 1976. The Broken Covenant: American Civil Religion in Time of Trial. Chicago, IL: University of Chicago Press.

Benen, Steve. 2014. "House Republicans Eye DOMA Sequel.” MSNBC Available at: http://www.msnbc.com/rachel-maddow-show/house-republicans-eye-doma-sequel. Accessed January 15, 2014.

Brewer, Marilynn B., Karen Gonsalkorale, and Andrea van Dommelen. 2013. "Social Identity Complexity: Comparing Majority and Minority Ethnic Group Members in a Multicultural Society." Group Processes \& Intergroup Relations 16(5):529-544.

Brewer, Marilynn B. and Kathleen P. Pierce. 2005. "Social Identity Complexity and Outgroup Tolerance.” Personality and Social Psychology Bulletin 31(3):428-437.

Burdette, Amy M., Christopher G. Ellison, and Terrence D. Hill. 2005. “Conservative Protestantism and Tolerance toward Homosexuals: An Examination of Potential Mechanisms.” Sociological Inquiry 75(2):177-196. 
Davis, Shannon N. and Theodore N. Greenstein. 2009. “Gender Ideology: Components, Predictors, and Consequences.” Annual Review of Sociology 35:87-105.

Denton, Melinda Lundquist. 2004. “Gender and Marital Decision Making: Negotiating Religious Ideology and Practice.” Social Forces 82:1151-1180.

Dougherty, Kevin D., Byron R. Johnson, and Edward C. Polson. 2007. "Recovering the Lost: Remeasuring U.S. Religious Affiliation.” Journal for the Scientific Study of Religion 46(4):483-499.

Falwell, Jerry. 1980. Listen America! Garden City, NY: Doubleday.

Fetner, Tina. 2008. How the Religious Right Shaped Lesbian and Gay Activism. Minneapolis, MN: University of Minnesota Press.

Froese, Paul and Christopher D. Bader. 2010. America's Four Gods: What We Say About God - and What That Says About Us. New York, NY: Oxford University Press.

Froese, Paul and F. Carson Mencken. 2009. “A U.S. Holy War? The Effects of Religion on Iraq War Policy Attitudes.” Social Science Quarterly 90(1):103-116.

Gorski, Philip S. 2010. Civil Religion Today (ARDA guiding paper series). State College, PA: The Association of Religion Data Archives at The Pennsylvania State University, from http://www.thearda.com/rrh/papers/guidingpapers.asp. Accessed November 22, 2013.

Haider-Markel, Donald P. and Mark R. Joslyn. 2008. "Beliefs about the Origins of Homosexuality and Support for Gay Rights: An Empirical Test of Attribution Theory." Public Opinion Quarterly 72(2):291-310.

Herek, Gregory M. 2002. “Gender Gaps in Public Opinion about Lesbians and Gay Men.” The Public Opinion Quarterly 66:40-66.

Hill, Terrence D., Benjamin E. Moulton, and Amy M. Burdette. 2004. “Conservative Protestantism and Attitudes Toward Homosexuality: Does Political Orientation Mediate this Relationship?” Sociological Focus 37:59-70. 
Karpov, Vyacheslav. 2002. "Religiosity and Tolerance in the United States and Poland." Journal for the Scientific Study of Religion 41(2):267-288.

Kuwabara, Ko, Robb Willer, Michael W. Macy, Rie Mashima, Shigeru Terai, and Toshio Yamagishi. 2007. "Culture, Identity, and Structure in Social Exchange: A Web-based Trust Experiment in the United States.” Social Psychology Quarterly 70:461-479.

Kite, Mary E. and Bernard E. Whitley. 1996. "Sex Differences in Attitudes Toward Homosexual Persons, Behaviors, and Civil Rights: A Meta-analysis.” Personality and Social Psychology Bulletin 22(4):336-353.

Linton, Paul Benjamin, Christopher M. Gacek, and Thomas Brejcha. 2013. "Brief Amicus Curiae of the Family Research Council in Support of Petitioners Addressing the Merits and Supporting Reversal.” Available at: www.americanbar.org/content/dam/aba/ publications/supreme_court_preview/briefs-v2/12144_pet_amcu_merits_rev_frc. authcheckdam.pdf. Accessed November 22, 2013.

Martin, Patricia Yancey. 2004. “Gender as a Social Institution.” Social Forces 82(4):1249-1273.

McDaniel, Eric L., Irfan Nooruddin, and Allyson F. Shortle. 2011. "Divine Boundaries: How Religion Shapes Citizens' Attitudes toward Immigrants.” American Politics Research 39(1):205-233.

Merino, Stephen M. 2010. “Religious Diversity in a 'Christian Nation': The Effects of Theological Exclusivity and Interreligious Contact on the Acceptance of Religious Diversity." Journal for the Scientific Study of Religion 49(2):231-246.

Merino, Stephen M. 2013. "Contact with Gays and Lesbians and Same-Sex Marriage Support: The Moderating Role of Social Context.” Social Science Research 42:1156-1166.

Meyers, Lawrence S., Glenn Gamst and A. J. Guarino. 2006. Applied Multivariate Research: Design and Interpretation. Thousand Oaks, CA: Sage. 
Olson, Laura R., Wendy Cadge, and James T. Harrison. 2006. "Religion and Public Opinion about Same-Sex Marriage. Social Science Quarterly 87:340-60.

Pampel, Fred C. 2000. Logistic Regression: A Primer. Thousand Oaks, CA: Sage Publications.

Perry, Samuel L. 2013. "Multiracial Church Attendance and Support for Same-Sex Marriage and Family Relationships.” Sociological Inquiry 83(2):259-285.

Regnerus, Mark D. and Christian Smith. 1998. “Selective Deprivation among American Religious Traditions: The Reversal of the Great Reversal." Social Forces 76(4):1347-72.

Roccas, Sonia and Marilynn B. Brewer. 2002. “Social Identity Complexity.” Personality and Social Psychology Review 6(2):88-106.

Rubin, Donald B. 1996. "Multiple Imputation after 18+ Years.” Journal of the American Statistical Association 91(434):473-489.

Schmid, Katharina, Miles Hewstone, Beate Küpper, Andreas Zick, and Ulrich Wagner. 2012. "Secondary Transfer Effects of Intergroup Contact: A Cross-National Comparison in Europe.” Social Psychology Quarterly 75(1):28-51.

Sherkat, Darren E., Kylan Mattias de Vries, and Stacia Creek. 2010. "Race, Religion, and Opposition to Same-Sex Marriage.” Social Science Quarterly 91(1):80-98.

Sherkat, Darren E., Melissa Powell-Williams, Gregory Maddox, and Kylan Mattias de Vries. 2011. "Religion, Politics, and Support for Same-Sex Marriage in the United States, 1988-2008." Social Science Research 40:167-180.

Skocpol, Theda and Vanessa Williamson. 2012. The Tea Party and the Remaking of Republican Conservatism. New York, NY: Oxford University Press.

Smith, Christian. 2000. Christian America?: What Evangelicals Really Want. Berkeley, CA: California University Press.

Sprigg, Peter. 2011. "The Top Ten Harms of Same-Sex 'Marriage."' Family Research Council. Available at: http://downloads.frc.org/EF/EF11B30.pdf. Accessed January 15, 2014 
Steensland, Brian, Jerry Z. Park, Mark D. Regnerus, Lynn D. Robinson, W. Bradford Wilcox, and Robert D. Woodberry. 2000. “The Measure of American Religion: Toward Improving the State of the Art." Social Forces 79(1):291-318.

Stroope, Samuel, Scott Draper, and Andrew L. Whitehead. 2013. "Images of a Loving God and Sense of Meaning in Life." Social Indicators Research 111(1):25-44.

Sutton, Matthew Avery. 2012. Jerry Falwell and the Rise of the Religious Right: A Brief History with Documents. Boston, MA: Bedford-St. Martin's.

Whitehead, Andrew L. 2010. “Sacred Rites and Civil Rights: Religion's Effect on Attitudes toward Same-Sex Unions and the Perceived Cause of Homosexuality." Social Science Quarterly 91:63-78.

Whitehead, Andrew L. 2012. "Religious Organizations and Homosexuality: The Acceptance of Gays and Lesbians in American Congregations.” Review of Religious Research 55:297-317.

Whitehead, Andrew L. 2014a. "Male and Female He Created Them: Gender Traditionalism, Masculine Images of God, and Attitudes toward Same-Sex Unions. Journal for the Scientific Study of Religion 53(3):479-496.

Whitehead, Andrew L. 2014b. "Politics, Religion, Attribution Theory, and Attitudes toward SameSex Unions.” Social Science Quarterly 95(3):701-718.

Whitehead, Andrew L. and Samuel L. Perry. 2014. "Religion and Support for Adoption by Same-Sex Couples: The Relative Effects of Religious Tradition, Practices, and Beliefs.” Journal of Family Issues DOI: 10.1177/0192513X14536564.

Wuthnow, Robert. 1988. The Restructuring of American Religion. Princeton, NJ: Princeton University Press. 
Table 1: Descriptive and Bivariate Statistics (MI Data)

\begin{tabular}{|c|c|c|c|c|c|}
\hline Variable & Description & $\begin{array}{l}\text { Mean } \\
\text { or } \%\end{array}$ & SD & $\begin{array}{l}\text { Correlation } \\
\text { w/ Civil } \\
\text { Unions }\end{array}$ & $\begin{array}{l}\text { Correlation } \\
\text { w/ Marriage }\end{array}$ \\
\hline $\begin{array}{l}\text { Agree to Same-Sex Civil } \\
\text { Unions }\end{array}$ & $\begin{array}{l}1=\text { Agree }, \text { Strongly } \\
\text { Agree }\end{array}$ & $55.8 \%$ & --- & 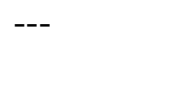 & --- \\
\hline $\begin{array}{l}\text { Agree to Same-Sex } \\
\text { Marriage }\end{array}$ & $\begin{array}{l}1=\text { Agree }, \text { Strongly } \\
\text { Agree }\end{array}$ & $33.4 \%$ & --- & --- & --- \\
\hline $\begin{array}{l}\text { Christian Nationalism } \\
(\alpha=0.87)\end{array}$ & $\begin{array}{l}\text { Summed index, } 6=\text { Low } \\
\text { to } 30=\text { High }\end{array}$ & 17.98 & 6.41 & $-0.58 * * *$ & $-0.63 * * *$ \\
\hline Age & Age in years, 18 to 96 & 50.95 & 16.41 & $-0.06^{*}$ & $-0.14 * * *$ \\
\hline Female & $1=$ Female & $55.4 \%$ & --- & 0.02 & 0.05 \\
\hline Non-White & $1=$ Non-White & $5.2 \%$ & --- & $-0.06^{*}$ & -0.04 \\
\hline South & $1=$ South & $30.9 \%$ & --- & $-0.16^{* * *}$ & $-0.12 * * *$ \\
\hline Married & $1=$ Married & $67.1 \%$ & --- & -0.03 & $-0.08 * * *$ \\
\hline Income & $\begin{array}{l}1=\$ 10,000 \text { or less to } 7= \\
\$ 150,000 \text { or more }\end{array}$ & 4.43 & 1.54 & $0.22 * * *$ & $0.12 * * *$ \\
\hline Education & $\begin{array}{l}1=8^{\text {th }} \text { grade or less, } 7= \\
\text { postgraduate work } / \text { degree }\end{array}$ & 4.66 & 1.63 & $0.28 * * *$ & $0.18 * * *$ \\
\hline Politically Conservative & $\begin{array}{l}1=\text { Liberal to } 7= \\
\text { Conservative }\end{array}$ & 4.29 & 1.61 & $-0.41 * * *$ & $-0.59 * * *$ \\
\hline Homosexuality Innate & $1=$ Homosexuality Innate & $46.1 \%$ & --- & $0.50 * * *$ & $0.46 * * *$ \\
\hline $\begin{array}{l}\text { Traditional Gender-Role } \\
\text { Beliefs Index }(\alpha=0.74)\end{array}$ & $\begin{array}{l}\text { Summed index, } 4= \\
\text { Egalitarian to } 20= \\
\text { Conservative }\end{array}$ & 9.95 & 3.69 & $-0.48 * * *$ & $-0.46 * * *$ \\
\hline God is a "he" & $1=$ God is a "he" & $27.8 \%$ & --- & $-0.37 * * *$ & $-0.29 * * *$ \\
\hline Biblical Literalist & $1=$ Biblical literalist & $20.7 \%$ & --- & $-0.44 * * *$ & $-0.30 * * *$ \\
\hline Biblical Interpretation & 1 = Interpret Bible & $36.1 \%$ & --- & $-0.06^{*}$ & $-0.22 * * *$ \\
\hline Bible Contains Errors & $1=$ Errors in Bible & $12.2 \%$ & --- & $0.15^{* * *}$ & $0.09 * * *$ \\
\hline Bible Ancient Book & $1=$ Bible ancient book & $25.4 \%$ & --- & $0.37 * * *$ & $0.48 * * *$ \\
\hline Bible Undecided & $1=$ Don't know & $5.6 \%$ & --- & -0.02 & -0.01 \\
\hline $\begin{array}{l}\text { Religious Practice Index } \\
(\alpha=0.84)\end{array}$ & $\begin{array}{l}\text { Standardized and } \\
\text { summed index }-4.13= \\
\text { least involved to } 4.16= \\
\text { most involved }\end{array}$ & 0.00 & 2.60 & $-0.44 * * *$ & $-0.45 * * *$ \\
\hline Evangelical Protestant & $\begin{array}{l}1=\text { Evangelical } \\
\text { Protestant }\end{array}$ & $30.4 \%$ & --- & $-0.31 * * *$ & $-0.23 * * *$ \\
\hline Black Protestant & $1=$ Black Protestant & $3.7 \%$ & --- & $-0.08 * *$ & $-0.07 * *$ \\
\hline Mainline Protestant & $1=$ Mainline Protestant & $22.0 \%$ & --- & $0.09 * * *$ & 0.00 \\
\hline Catholic & $1=$ Catholic & $23.9 \%$ & --- & 0.04 & -0.04 \\
\hline Jewish & $1=$ Jewish & $2.2 \%$ & --- & $0.12 * * *$ & $0.11 * * *$ \\
\hline Other & $1=$ Other & $6.4 \%$ & --- & $0.07 * *$ & $0.07 * *$ \\
\hline No Religion & $1=$ No Religion & $11.1 \%$ & --- & $0.22 * * *$ & $0.31 * * *$ \\
\hline
\end{tabular}

Source: BRS (2007)

$* \mathrm{p}<.05 ; * * \mathrm{p}<.01 ; * * * \mathrm{p}<.001$ 
Table 2: Logistic Regression Analysis of Christian Nationalism Predicting Support for Same-Sex Marriage (MI Data)

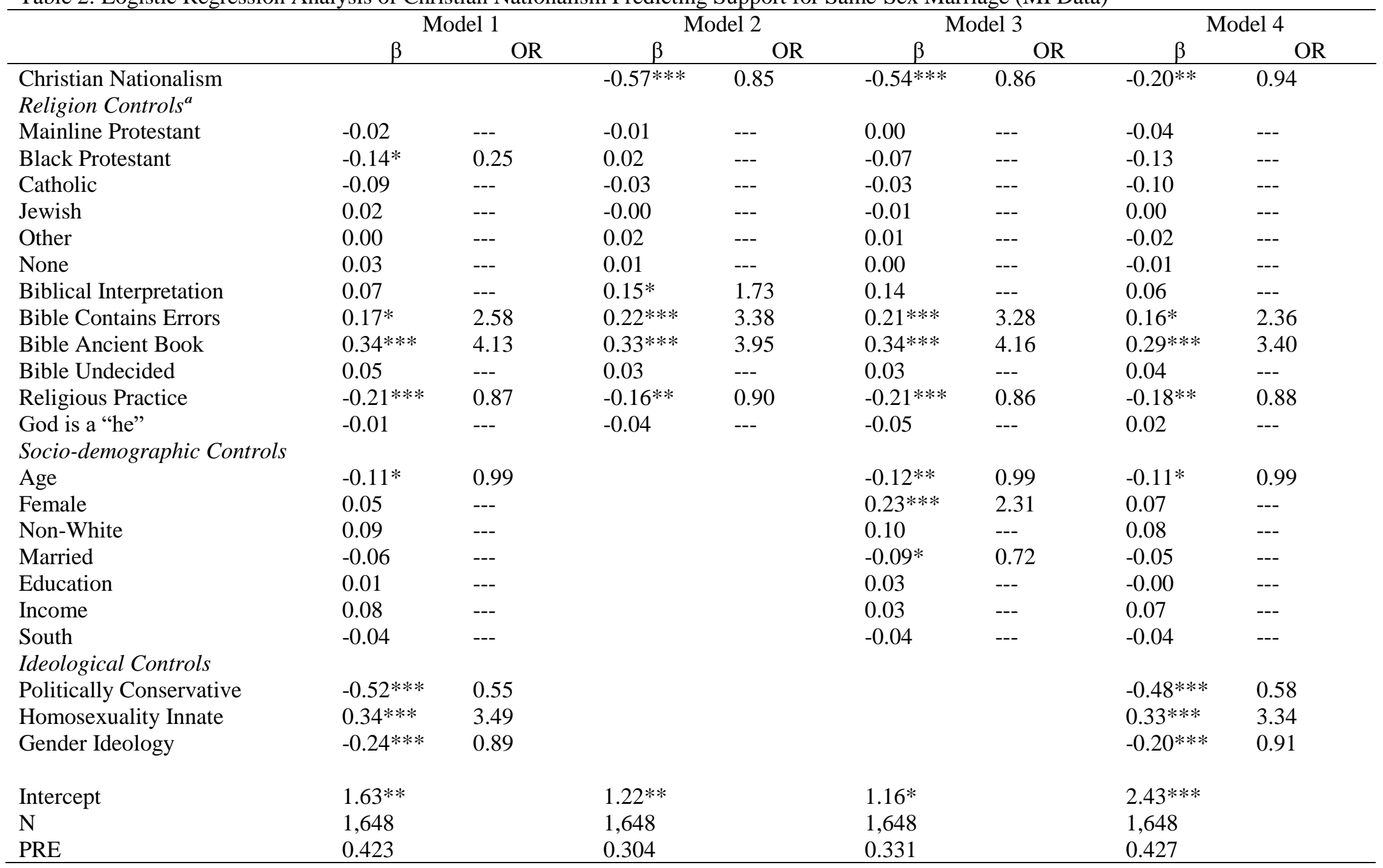

*p $<.05 ; * * \mathrm{p}<.01 ; * * * \mathrm{p}<.001$

$\beta=$ Standardized Coefficient; OR = Odds Ratio

PRE $=$ Proportional Reduction in Error (Likelihood Ratio/-2 Log Likelihood)

${ }^{a}$ Evangelical Protestant and Biblical Literalist are contrast categories 
Table 3: Logistic Regression Analysis of Christian Nationalism Predicting Support for Same-Sex Civil Unions (MI Data)

\begin{tabular}{|c|c|c|c|c|c|c|c|c|}
\hline & \multicolumn{2}{|c|}{ Model 1} & \multicolumn{2}{|c|}{ Model 2} & \multicolumn{2}{|c|}{ Model 3} & \multicolumn{2}{|c|}{ Model 4} \\
\hline & $\beta$ & $\mathrm{OR}$ & $\beta$ & OR & $\beta$ & OR & $\beta$ & OR \\
\hline Christian Nationalism & & & $-0.51 * * *$ & 0.87 & $-0.46 * * *$ & 0.88 & $-0.30 * * *$ & 0.92 \\
\hline \multicolumn{9}{|l|}{ Religion Controls $^{a}$} \\
\hline Mainline Protestant & 0.03 & --- & $0.10^{*}$ & 1.56 & 0.07 & --- & 0.03 & --- \\
\hline Black Protestant & -0.08 & --- & 0.04 & --- & -0.03 & --- & -0.06 & --- \\
\hline Catholic & -0.01 & --- & 0.06 & --- & 0.02 & --- & -0.02 & --- \\
\hline Jewish & 0.07 & --- & 0.09 & --- & 0.04 & --- & 0.04 & --- \\
\hline Other & 0.06 & --- & 0.06 & --- & 0.05 & --- & 0.04 & --- \\
\hline None & 0.06 & --- & 0.02 & --- & 0.02 & --- & 0.00 & --- \\
\hline Biblical Interpretation & $0.24 * * *$ & 2.43 & $0.28 * * *$ & 2.92 & $0.27 * * *$ & 2.80 & $0.23 * * *$ & 2.34 \\
\hline Bible Contains Errors & $0.24 * * *$ & 3.80 & $0.28 * * *$ & 4.84 & $0.26 * * *$ & 4.28 & $0.23 * * *$ & 3.53 \\
\hline Bible Ancient Book & $0.34 * * *$ & 4.19 & $0.35 * * *$ & 4.34 & $0.32 * * *$ & 3.78 & $0.29 * * *$ & 3.29 \\
\hline Bible Undecided & 0.02 & --- & 0.01 & --- & 0.00 & --- & 0.00 & --- \\
\hline Religious Practice & $-0.21 * * *$ & 0.86 & $-0.15^{* *}$ & 0.90 & $-0.24 * * *$ & 0.85 & $-0.17 * *$ & 0.89 \\
\hline God is a "he" & $-0.12 * *$ & 0.62 & $-0.10 * *$ & 0.65 & $-0.11 * *$ & 0.63 & -0.09 & --- \\
\hline \multicolumn{9}{|c|}{ Socio-demographic Controls } \\
\hline Age & 0.02 & --- & & & 0.02 & --- & 0.03 & --- \\
\hline Female & 0.06 & --- & & & $0.19 * * *$ & 2.03 & $0.08 *$ & 1.35 \\
\hline Non-White & 0.11 & --- & & & 0.11 & --- & 0.10 & --- \\
\hline Married & -0.05 & --- & & & -0.06 & --- & -0.04 & --- \\
\hline Education & $0.20 * * *$ & 1.25 & & & $0.18 * * *$ & 1.23 & $0.19 * * *$ & 1.23 \\
\hline Income & $0.16^{* *}$ & 1.21 & & & $0.16^{* *}$ & 1.21 & $0.15^{* *}$ & 1.20 \\
\hline South & $-0.10 *$ & 0.68 & & & $-0.10 * *$ & 0.68 & $-0.10 *$ & 0.70 \\
\hline \multicolumn{9}{|l|}{ Ideological Controls } \\
\hline Politically Conservative & $-0.13 * *$ & 0.86 & & & & & -0.06 & --- \\
\hline Homosexuality Innate & $0.38 * * *$ & 3.98 & & & & & $0.37 * * *$ & 3.85 \\
\hline Gender Ideology & $-0.25 * * *$ & 0.89 & & & & & $-0.20 * * *$ & 0.91 \\
\hline Intercept & $-1.15^{*}$ & & $1.86^{* * *}$ & & -0.23 & & 0.05 & \\
\hline $\mathrm{N}$ & 1,648 & & 1,648 & & 1,648 & & 1,648 & \\
\hline PRE & 0.379 & & 0.295 & & 0.333 & & 0.389 & \\
\hline
\end{tabular}

$* \mathrm{p}<.05 ; * * \mathrm{p}<.01 ; * * * \mathrm{p}<.001$

$\beta=$ Standardized Coefficient; OR = Odds Ratio

PRE = Proportional Reduction in Error (Likelihood Ratio/-2 Log Likelihood)

${ }^{a}$ Evangelical Protestant and Biblical Literalist are contrast categories 
Figure 1: Percent Supporting Same-Sex Marriage and Civil Unions at Varying Levels of Christian Nationalism

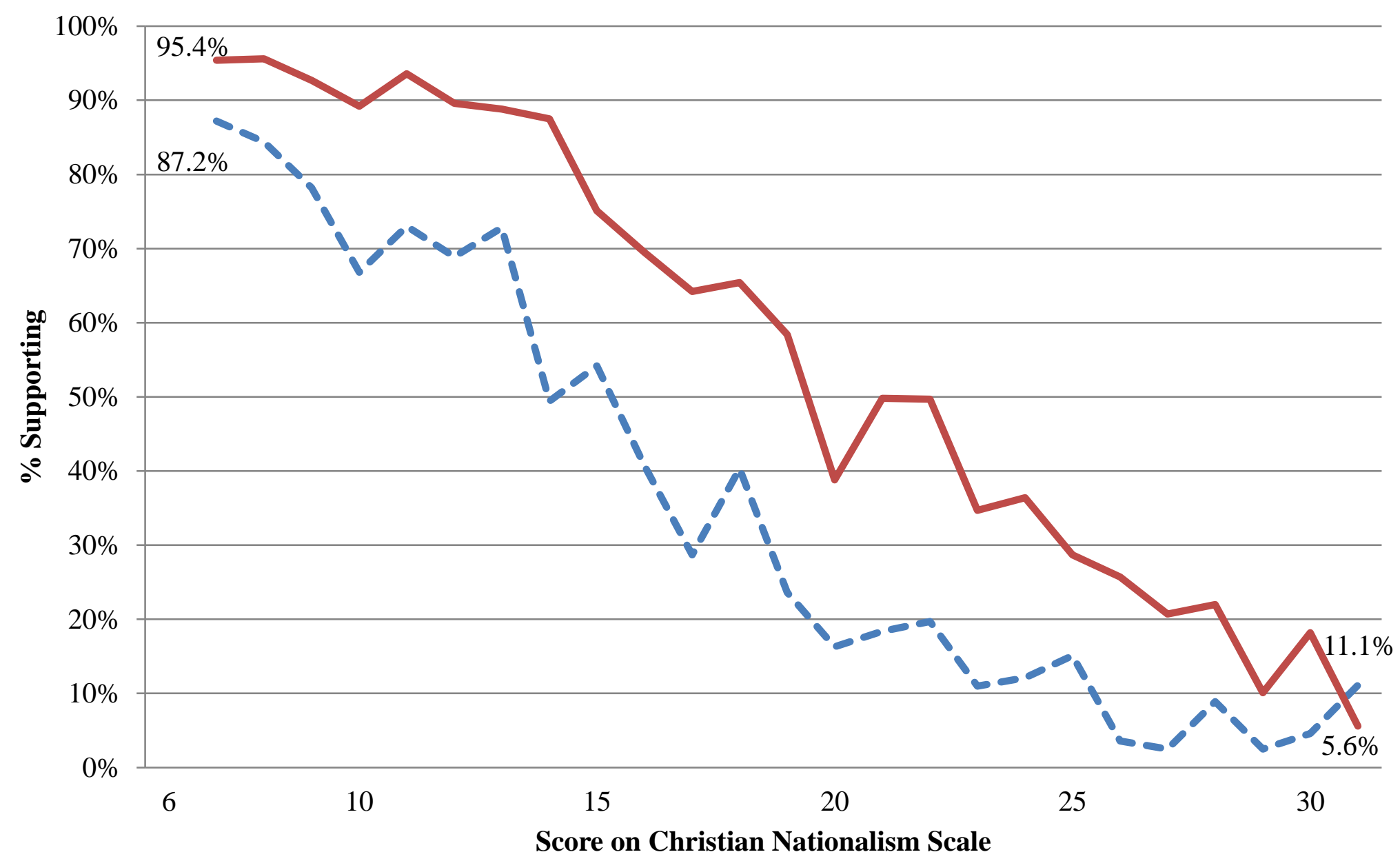

- \% Supporting Same-Sex Marriage

$\%$ Supporting Same-Sex Civil Unions 
Figure 2: Predicted Probabilities of Support for Same-Sex Marriage and Civil Unions at Varying Levels of Christian Nationalism

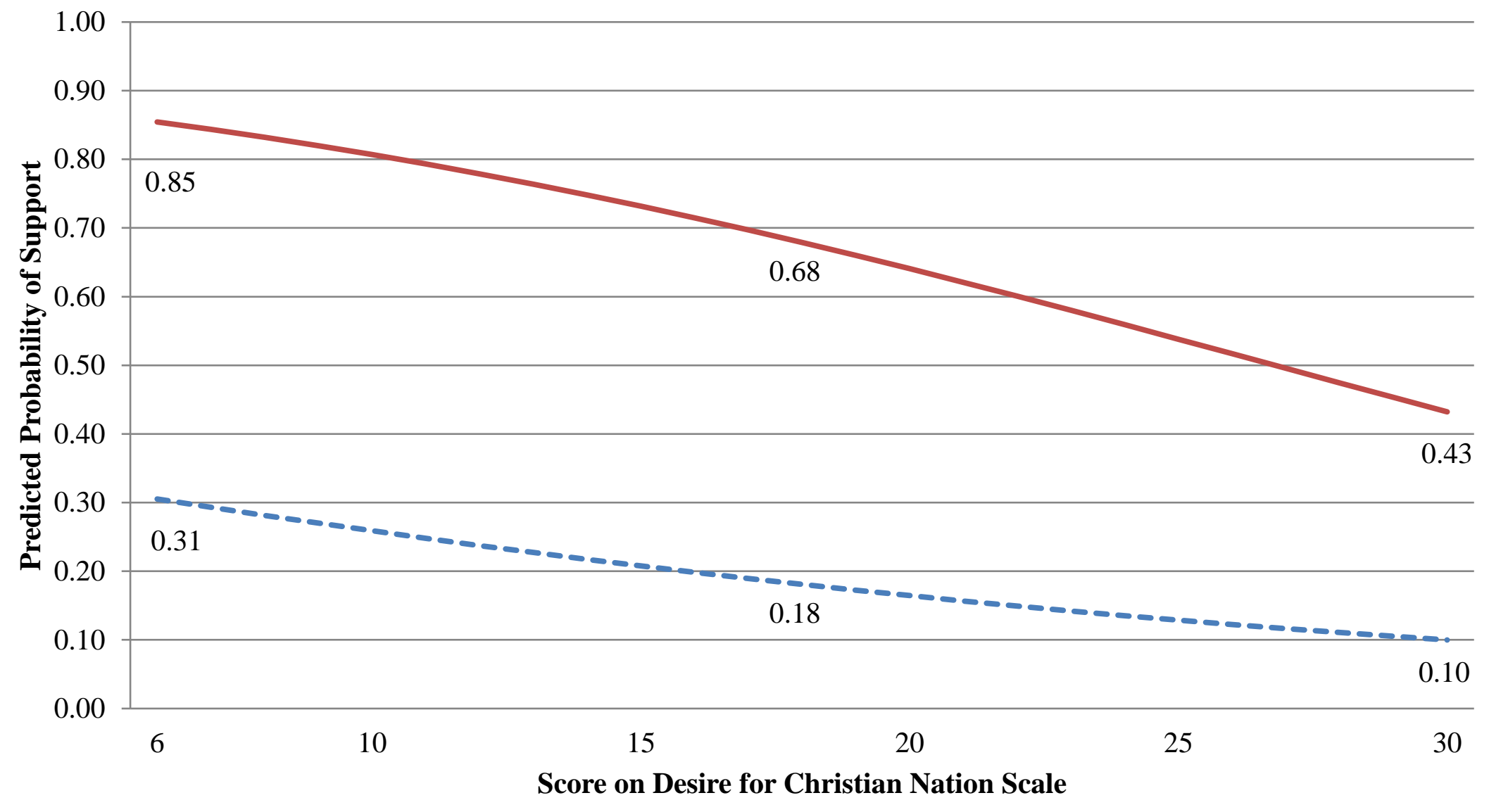

- - - Support Same-Sex Marriage — $\quad$ Support Same-Sex Civil Unions

Note: All significant effects for both models are set to their means when estimating predicted probabilities 


\section{Endnotes}

${ }^{1}$ A 2013 Pew survey found $41 \%$ of Americans still oppose same-sex marriage.

${ }^{2}$ We find in ancillary analyses that Christian nationalists are much more likely to be gender traditionalists than the general population (see footnote 5 below).

${ }^{3}$ Evidence of this ideology at work is found in the amicus briefs filed when the Supreme Court heard arguments concerning the Defense of Marriage Act and Proposition 8. In the amicus brief filed by the Family Research Council (FRC), an organization that self-identifies as one "dedicated to the promotion of marriage and family ... in national policy," this ideology is clearly shown.

"FRC champions marriage and family as the foundation of civilization, the source of virtue and the wellspring of society. Believing that God is the author of life, liberty, and family, FRC promotes the Judeo-Christian world view as the basis for a just, free and stable society. Consistent with its mission statement, FRC is committed to strengthening traditional families in America ... Recognition of same-sex marriages would not promote either of the principal interests on which opposite-sex marriage is a protected institution ..." (Linton, Gacek, and Brejcha 2013: 1-2).

${ }^{4}$ An obvious weakness of these measures is that they conflate respondents' attitudes toward gay men and lesbians by only asking about their attitudes toward "homosexuals" in general (Herek 2002; Kite and Whitley 1996). While measuring attitudes toward gay men and lesbians separately would be ideal, public rhetoric commonly utilizes "homosexuality" without distinguishing between gay men and lesbians (Herek 2002). Thus, lesbians and gay men share a "common characteristic that makes them members of a distinct quasi-ethnic group with its own culture and political concerns" (Herek 2002:42) suggesting that these measures tap into the broader set of attitudes maintained by a majority of the public despite not being able to distinguish between attitudes toward lesbians and gay men. ${ }^{5}$ Who are Christian nationalists? Looking at those who score in the upper quartile of the Christian nationalism measure (score of 23 or more on the scale) we find that Christian nationalists are more likely to be Evangelical and Black Protestants compared to the total sample (and less likely to be Mainline, Catholic, Jewish, Other, or None), biblical literalists, religiously active, political conservatives, gender traditionalists, southerners, earn less, less educated, and female. Christian nationalists are not significantly more likely to be married, older, or white, however. ${ }^{6}$ In additional analyses and following Sherkat et al. 2010 we also coded Evangelical Protestants and Black Protestants as one category given that African Americans involved in Protestant denominations tend to be more opposed to civil rights for same-sex couples than other African Americans. There were no substantive differences between the additional analyses and those in this manuscript.

${ }^{7}$ See Dougherty, Johnson, and Polson (2007) for further details of the methodology used to identify religious tradition in the Baylor Religion Surveys.

${ }^{8}$ We also utilized political party identification (see Sherkat et al. 2011) in separate models and the results were unchanged.

${ }^{9}$ These are estimated as $B_{y x}^{*}=b_{y x}\left(s_{x} / s_{y}\right)$ and we follow Pampel's (2000) assumption that the standard deviation of $\operatorname{logit}(\mathrm{y})=1.8138$.

${ }^{10}$ As with all studies utilizing a large number of religion and politics measures, multicollinearity in the multivariate models can become problematic. Investigating the correlations between all of the independent variables reveals that none exceed the classic cut-off point of 0.70 (results available upon request). Going one step further, we assessed multicollinearity in our binary logistic models by inspecting variance inflation factor scores (VIF) in an ordinary least squares model (Allison 2001; Stroope et al. 2013). We find our VIF scores do not exceed 3.5, which is well below the standard of a VIF greater than 10 as problematic (Meyers, Gamst, and Guarino 2006). Finally, the maximum likelihood estimation procedure used in logistic regression is less susceptible to issues arising from multicollinearity compared to standard ordinary least squares techniques.

11 The predicted probabilities hold all significant effects from each dependent variable's full model at their means.

12 The MI procedure generates five imputations using multiple Markov Chains based on all variables included in each model, resulting in an overall $\mathrm{N}$ of 8,240 (1,648 X 5). All results use the MI dataset. The correlations reported in Table 1 and all of the results reported in Tables 2 and 3 are from the MIANALYZE procedure in SAS. This procedure combines all of the results from each of the five imputations resulting in overall estimates, standard errors, and significance levels. The standardized coefficients and odds ratios for each model were calculated using 
these overall estimates. The Proportional Reduction in Error (PRE) reported in Tables 2 and 3 for each model are the average of the PRE for each individual iteration.

${ }^{13}$ To calculate the percent odds decrease for a negative odds ratio, in this case 0.94 , we divide 1 by 0.94 . This corrects for the bounded nature of negative odds ratios between 0 and 1. For the Christian nationalism scale, the calculation is as follows: $1 / 0.94=1.064$.

${ }^{14} 1 / 0.92=1.087$. See endnote 13 for explanation of transforming negative odds ratios.

${ }^{15}$ Ancillary analyses (available upon request) further demonstrate that regardless of political ideology or religious behavior, Christian nationalists are less likely to support same-sex marriage. For example, a political moderate who strongly identifies as a Christian nationalist has a lower probability of supporting same-sex marriage than a political conservative who does not identify as a Christian nationalist. Individuals who report low levels of religious behavior but strongly identify as a Christian nationalist are actually less likely to support same-sex unions compared to someone who reports high levels of religious activity but does not identify as a Christian nationalist.

${ }^{16}$ We are thankful to the editors for pointing out this strength of the 2007 data. 